\begin{tabular}{|c|c|c|}
\hline A & $\begin{array}{c}\text { International Journal of Current Research } \\
\text { and Academic Review }\end{array}$ & \\
\hline $\begin{array}{l}\text { EXCELLENT } \\
\text { PUBLISHERS }\end{array}$ & $\begin{array}{c}\text { ISSN: 2347-3215 (Online) } \because,: \text { Volume } 5: ; \quad \text { Number } 12 \text { (December-2017) } \\
\text { Journal homepage: http://www.ijcrar.com }\end{array}$ & \\
\hline
\end{tabular}

doi: https://doi.org/10.20546/ijcrar.2017.512.005

\title{
Elastin Structure Protein Non-Enzymatic Glycation Inhibition Studies by Use of Secondary Metabolites of Withania somnifera
}

\author{
Mohammad Nadeem Khan* \\ SOS in Biotechnology, Bastar University, Jagdalpur (C.G.) 494001, India \\ *Corresponding author
}

\section{Abstract}

NEGs (non-enzymatic glycation) accumulations particularly high in E.C.M., proteins are result in intra and inter molecular cross-linking and later has been hypotized to stiffening of these proteins and believed to play an important role in etiology of various NEGs related diseases (Basta et al., 2004). The goal of this research asses the energy level of W. somnifera (Withaferin -A) in Elastin (hydrophobic) structural protein interaction that made glycation adducts with glucose. The results level of binding energy of proteins and phyto constituents are high in Elastin (-8.4). The glucose and protein binding energy Elastin (-3.9). The energy level of Elastin high that's clear indication that withaferin-A give best result of inhibitions was compared with glucose and protein binding energy. This preliminary finding gives an open window towards structure based drug design to finding noval inhibitory molecule of entities.
\end{abstract}

\section{Article Info}

Accepted: 28November 2017

Available Online: 20 December 2017

\section{Keywords}

Non-enzymatic glycation,

Docking,

Binding energy,

Half-life,

In-silico

\section{Introduction}

NEG is result of sugar molecules such as glucose, fructose bonding to a protein or lipid molecule without controlling action of an enzyme. These are implicated in many age related diseases such as type-II (diabetic mellitus), cardiovascular disease (collagen, fibrinogen are damaged), Alzheimer diseases (amyloid protein product of the reaction progressing to AGEs), Cancer (acryl-amide and other product related), peripheral neuropathy (myelin is attached), and other sensory losses (de-myelination), and blindness (due to micro-vascular damage in the retina), this range of diseases is the result of very basic level at which glycation interfere with molecular and cellular functioning throughout the body (Vorum et al., 1995). The long half-life proteins of the extracellular matrix (E.C.M.), typically Elastin (hydrophobic) (Basta et al., 2004), accumulate reactive metabolites through uncontrolled non-enzymatic reactions such as glycation or atypical example of these non-enzymatic changes is the formation of advanced glycation end-products (AGEs), resulting from the reaction of carbohydrates with the free amino group of proteins (Rebecca et al., 2008). The accumulation of AGEs and the resulting structural alterations cause tissue conventional properties (increased stiffness, reduced elasticity). Withania somnifera (Sanskrit: Ashwagandha, English: Winter cherry). Withania somnifera, commonly known as Ashwagandha, is a valued herb in Ayurvedic medicine. Roots, leaves and preparations of the plant are traditionally used as tonic, hypnotic, sedative and diuretic. W. somnifera mainly contains with anolides including withaferin-A which are specific to the Solanaceae family. With anolides are biologically active secondary metabolites present in roots and leaves of $W$. somnifera. The present study provides examples of the 
anti-glycation activity of $W$. somnifera, phyto constituents Withaferin-A, which target the essential stages of glycation through-(i) inhibition of nonenzymatic glycation/ AGEs. To best of our knowledge, the receptor-level mechanism behind this process is nowhere mentioned. Present research was emphasis at the analysis of receptor-level binding affinity of Elastin with Withaferin-A and Glucose through molecular docking. In-silico studies would provide a clear understanding on the mode of action of the above mentioned Withaferin-A components against Structural E.C.M. protein can be used as inhibitory drug to reduce hyperglycemic related complications.

\section{Materials and Methods}

\section{Structure retrieval}

The protein data bank (PDB): The structure homologues for elastin and collagen protein Sequence query was retrieved in PDB.

The research collaboratory for structural bioinformatics (RCSB): The molecular shape of elastin was retrieved from RCSB PDB (PDB - www.rcsb.org/).

PDB sum: The PDB sum (PDB sumwww.ebi.ac.uk/pdbsum/), a pictorial database that provides an at-a-glance overview of the contents of each 3D structure deposited in the Protein Data Bank (PDB) was used to get the 3-D structure of elastin.

Structure visualization-RASMOL: RasMol (RasMolwww.rasmol.org/), a molecular graphics program intended for the visualization of proteins, used for structural visualization of elastin. Three dimensional structure of inhibitors-CHEMSKETCH: The Chemical structure of Withaferin-A, (Chem Sketchwww.acdlabs.com/download/), a quite powerful chemical structure drawing program.

Docking: Docking was done with the PyRx software (pyrax-www.pyraxviana.com/), in which the result is being obtained on the basis of pose energy. Docking calculations attempt to place 'Ligand into Binding Sites'.

The binding affinity was expressed $\mathrm{kcal} / \mathrm{mol}$. The atoms that make up the Ligand like inhibitor, and the Binding Site on the protein where the inhibitors bind that Structure were drawn in Discovery studio 2.1 version.

\section{Results and Discussion}

The structural E.C.M. proteins (Elastin) were retrieved and analyzed and it was docked to Withaferin-A from $W$. somnifera (figure-1) and glucose that is responsible from non-enzymatic glycation.

The results and visualize data /figures are presented as follows:

Figure 2 shows the wireframe, ball stick, ball stick spacefill, ribbon, cartoon diagram of Elastin receptors, which were downloaded from PDB and visualize by use of RasMol software. The specification of proteins described $\mathrm{n}$ table no.1.the technical specification of ligands summarized $n$ table no.2. Ball \& stick, wireframe, sticks, dots and dots with space-fill model of Withaferin-A and Glucose are depicted in Figure 3, 4. After docking, both compounds bound exactly at the active site of Elastin, which was shown in Frame. A careful inspection of the binding pocket indicated that both the compounds at the Withaferin-A, glucose domain of E.C.M. proteins Figure 5 and detail docking results were presented in table no.3.

Fig.1 Plant herbarium image

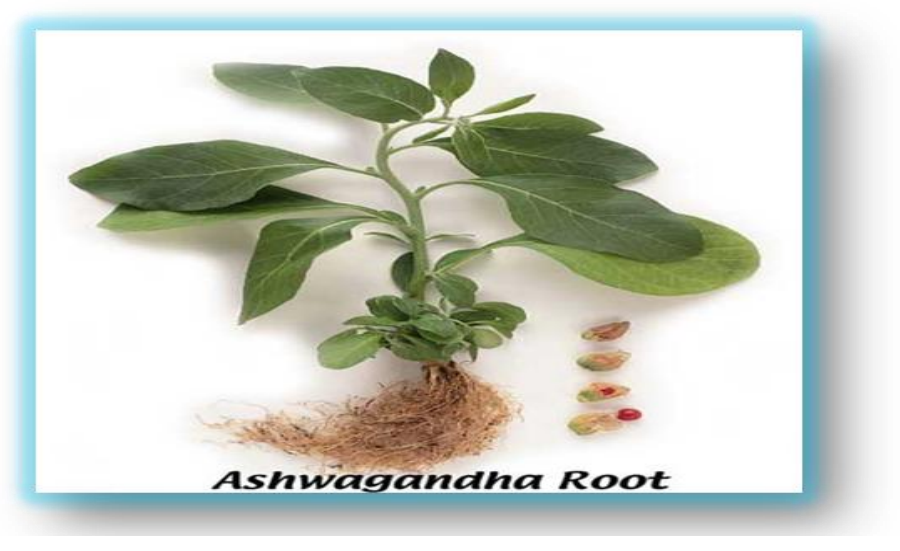


Fig.2 3D Structure Diagram of Elastin

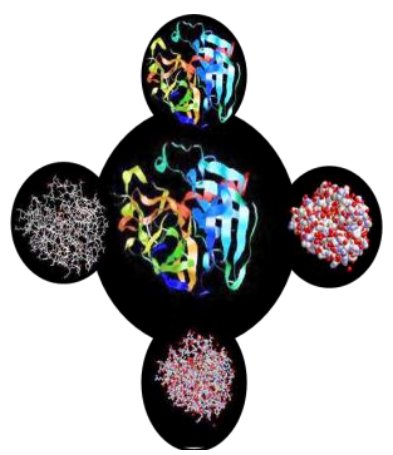

Fig.3 3D Structure of Withaferin-A

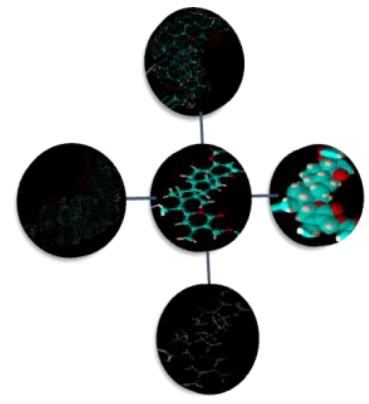

Fig.4 3D Structure of Glucose

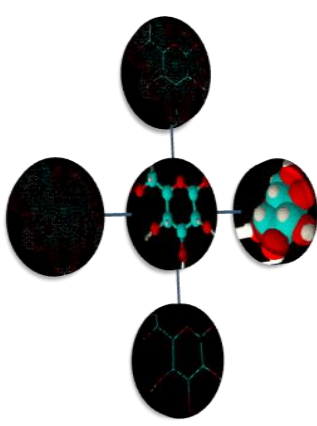

Fig.5 Glucose and Withaferin-A docked with the active site (sphere ball red color) of Elastin

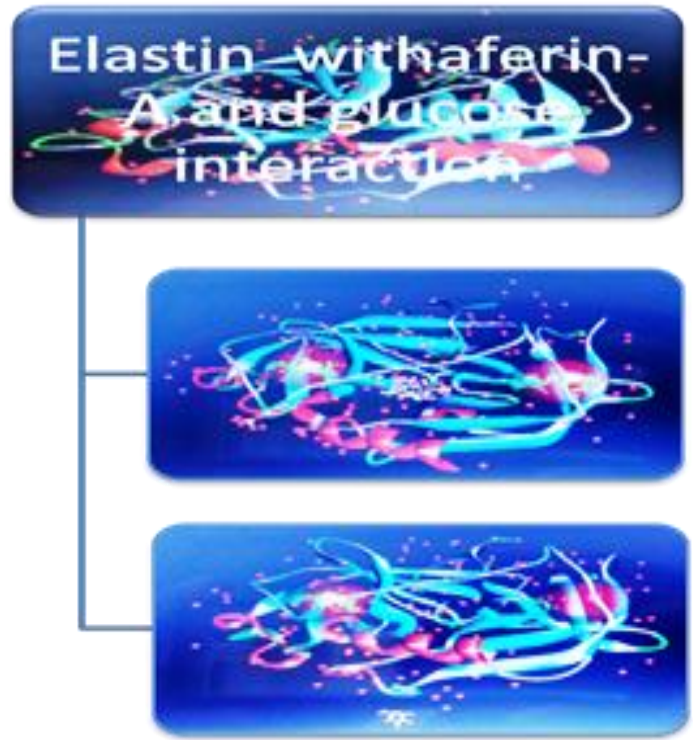


Table.1 Target Information

\begin{tabular}{|l|l|l|}
\hline S. no. & Specification & Elastin \\
\hline 1 & PDB ID & 2 oii \\
\hline 2 & Molecular size & 51681.58 \\
\hline 3 & Solubility & Hydrophobic \\
\hline 4 & Chain & $1,2,3$ \\
\hline 5 & Length & 162 \\
\hline 6 & Amino acids & 393 \\
\hline 7 & Type & Structural \\
\hline
\end{tabular}

Table.2 Properties of ligands acid obtained from Chem-Sketch

\begin{tabular}{|c|c|c|c|}
\hline S. no. & Parameters & Withaferin-A & Glucose \\
\hline 1 & PubChem ID & 265237 & 5793 \\
\hline 2 & $\begin{array}{l}\text { Chemical } \\
\text { Name }\end{array}$ & $\begin{array}{l}\text { 5,6-epoxy-4,22,27- } \\
\text { trihydroxy-1oxoergosta-2,24- } \\
\text { dienoic acid delta-lactone }\end{array}$ & $\begin{array}{c}\text { Glucose, (alpha-D)-Isomer; D-Glucose; D- } \\
\text { Glucopyranose; Glucose; Glucopyranose; Grape } \\
\text { sugar }\end{array}$ \\
\hline 3 & $\begin{array}{l}\text { Molecular } \\
\text { formula }\end{array}$ & $\mathrm{C}_{28} \mathrm{H}_{38} \mathrm{O}_{6}$ & $\mathrm{C}_{6} \mathrm{H}_{12} \mathrm{O}_{6}$ \\
\hline 4 & $\begin{array}{l}\text { Molecular } \\
\text { weight }\end{array}$ & $470.606 \mathrm{~mol} / \mathrm{grams}$ & $180.156 \mathrm{~mol} / \mathrm{grams}$ \\
\hline 5 & $\begin{array}{l}\text { Hydrogen } \\
\text { bond donor } \\
\text { count }\end{array}$ & 2 & 5 \\
\hline 6 & $\begin{array}{l}\text { Hydrogen } \\
\text { Bond } \\
\text { Acceptor } \\
\text { Count }\end{array}$ & 6 & 6 \\
\hline 7 & $\begin{array}{c}\text { Rota table } \\
\text { count }\end{array}$ & 3 & 1 \\
\hline 8 & $\begin{array}{l}\text { Topological } \\
\text { Surface area }\end{array}$ & $96.4 \mathrm{~A}^{\wedge} 2$ & $110 \mathrm{~A}^{\wedge} 2$ \\
\hline 9 & $\begin{array}{c}\text { Mono- } \\
\text { isotopic mass }\end{array}$ & $470.267 \mathrm{~g} / \mathrm{mol}$ & $180.063 \mathrm{~g} / \mathrm{mol}$ \\
\hline 10 & Exact Mass & $470.267 \mathrm{~g} / \mathrm{mol}$ & $180.063 \mathrm{~g} / \mathrm{mol}$ \\
\hline 11 & Melting point & ------- & $146 * \mathrm{c}$ \\
\hline
\end{tabular}

Table.3 The receptor-Ligand interaction details

\begin{tabular}{|c|c|c|c|c|c|}
\hline S. no & Ligands & receptor & Centre & $\begin{array}{l}\text { Number of } \\
\text { Binding } \\
\text { site(pose) }\end{array}$ & $\begin{array}{l}\text { Bnding score } \\
\text { (cal/mol) }\end{array}$ \\
\hline 1 & Withaferin-A & Elastin & $\begin{array}{c}X: 46.9380 \\
Y: 2.4375 \\
Z: 42.9441\end{array}$ & 7 & -8.4 \\
\hline 2 & Glucose & Elastin & $\begin{array}{c}X: 52.1256 \\
Y: 1.1728 \\
Z: 8.3721\end{array}$ & 8 & -3.9 \\
\hline
\end{tabular}


Structure based Drug discovery typically starts with an analysis of binding sites in target proteins, or an identification of structural motifs common to active compounds. In silico molecular docking is one of the most powerful techniques to discover novel ligands for receptors of known structure and thus play a key role in structure based drug design. The docking process involves the prediction of ligand confirmation and orientation (posing) within targeted binding site and their interaction energies were calculated using the scoring functions. An efficient inhibitor of non-enzymatic glycation should inhibit glucose-derived NEGs generation (Saxena, et al., 1996). A large number and ever increasing number of synthetic and natural "AGE Inhibitors" have been reported in past. because the mechanisms of non-enzymatic glycation or AGEs formation involve complex sequential and parallel reactions that are poorly understood ${ }^{4}$ had proposed a simple scheme that identifies common targets for AGEs inhibition, a guide and basis for rational design of new AGE inhibitors, an classification of existing AGE inhibitors.

AGE inhibitors can be classified in six categories or types (Kyselova et al., 2004) (Type-A, B, C, D, E, and F). This group reduces AGE toxicity by breaking protein-AGE cross-linking. In order to find which type of inhibition mechanism of action behind this process, we have taken E.C.M. proteins as a receptor and compounds and carried out docking process. It was clear from Table -3 Withaferin-A and Glucose docked with Elastin and collagen. As a result of docking, different conformations were generated for both compounds with E.C.M. proteins. The score and pose (site of interactions) clearly indicate that Withaferin-A capping the proteins and prevent to glucose to bind non-specifically with elastin and collagen protein. From these docking studies, hence we conclude that binding of Withaferin-A may lead good inhibitor of NEGs activity and reduce its related complications. However, this mechanism of prediction requires further advance in- silico analysis.

\section{References}

Basta, G.; Schmidt, A. M., and Decaterina, R. Advanced glycation end products and vascular inflammation: Implications for accelerated atherosclerosis in diabetes. Cardiovascular Research. (2004) 63, Pg. 582-592.

Khalifah, R.G.; Baynes, J. W. and Hudson B. G. Amadorins: novel post-Amadori inhibitors of advancedglycation reactions. Biochem. Biophys. Res. Commun, (1999)257; 251-258.

Kyselova, Z.; Stefek, M. and Bauer, V. Pharmacological prevention of diabetic cataract. J. Diab. Compli, (2004) 18; 129-140.

Lubeg, G.; Widness, J.A.; Hayde, M.; Menzel, D. and Pollak, A. Hydroxyl radical generation in oxygentreated infants. Pediatrics, (1997)100; 700-704.

McLean, W.G. The role of axonal cytoskeleton in diabetic neuropathy. Neurochem Res, (1997) 22; 951-956.

Rebecca, P.; Greenspan, D.P; Hartle, D.K.; Swanson, R.B. and James L. Inhibition of Protein Glycation by Extracts of Culinary Herbs and Spices. J. M. F., (2008)11; 275-281.

Sheikh, N.; Safari, M.R.; Kashani M.; Araghchian, M. and Zeraat, F. Study on the effect of garlic on the invitro albumin glycation reaction. Acta Medica Iranica, (2004)42; 16-18.

Vorum, H.; Fisker, K.; Otagiri, M.; Pedersen, A. O. and Hansen, U. K. Calcium ion binding to clinically relevant chemical modifications of human serum albumin. Clin. Chem. (1995) 41; 1654-1661.

\section{How to cite this article:}

Mohammad Nadeem Khan. 2017. Elastin Structure Protein Non-Enzymatic Glycation Inhibition Studies by Use of Secondary Metabolites of Withania somnifera. Int.J.Curr.Res.Aca.Rev. 5(12), 35-39.

doi: https://doi.org/10.20546/ijcrar.2017.512.005 